\title{
THE EPIDEMIOLOGY OF VIRUSES AFFECTING BUTTERCUP SQUASH PRODUCTION IN TONGA
}

\author{
V. KAMI ${ }^{1}$, M.N. PEARSON ${ }^{1}$ and J.G. CHARLES ${ }^{2}$ \\ ${ }^{1}$ School of Biological Sciences, University of Auckland, New Zealand \\ ${ }^{2}$ HortResearch, Private Bag 92169, Auckland, New Zealand \\ Corresponding author: pilakami@kalianet.to
}

Buttercup squash (Cucurbita maxima) is produced in Tonga for export to a niche market in Japan. It is the kingdom's major export commodity and involves several hundred small-scale farmers. Severe viral mosaics were first observed in the crop in 1991 , and since then virus diseases have adversely affected production. During a threeyear study (1999-2002) the presence of Zucchini yellow mosaic virus (ZYMV), Watermelon mosaic virus (WMV) and Cucumber mosaic virus (CMV) were confirmed by ELISA, often as mixed infections. ZYMV was the mostly frequently detected virus and was associated with the most severe symptoms. Buttercup squash grown in close proximity to watermelon expressing mosaic symptoms often showed higher levels of virus infection than crops farther away. Comparison of ZYMV isolates from squash and watermelon by RT-PCR and sequencing demonstrated that the same isolates were found in both crops.

\section{NOVEL TARGETS FOR SUSTAINABLE CONTROL OF APPLE BLACKSPOT}

\author{
R.W. CHYNOWETH ${ }^{1}$, S.S. HUNG ${ }^{2}$ and K.M. PLUMMER ${ }^{2}$ \\ ${ }^{1}$ HortResearch, Mt Albert, Private Bag 92196, Auckland, New Zealand \\ ${ }^{2}$ University of Auckland, Private Bag 92019, Auckland, New Zealand
}

Corresponding author: rchynoweth@hortreserach.co.nz.

Control options for black spot in organic orchards in NZ are limited. Several reports have shown that biocontrol agents can reduce incidence of Venturia inaequalis primary inoculum (ascospores) by degrading leaf litter or by direct antagonism of $V$. inaequalis. However, biocontrol agents have not had a significant impact on commercial production, partly due to the availability of chemical alternatives and partly to a lack of knowledge of how to utilise biocontrol agents to gain reliable control. Recent publications have revealed a class of small proteins (a-factor peptides) that are fungal mating pheromones (e.g. from the yeast, Saccharomyces cerevisiae). These proteins also inhibit infection structures produced by plant pathogenic fungi, such as the apple pathogen, Glomerella cingulata, and a rice pathogen, Magnaporthe grisea. One such protein (a-factor from $S$. cerevisiae) was tested in vitro for its effect on V. inaequalis. Conidia failed to germinate in the presence of $0.3 \mathrm{mM}$ of peptide, and formation of appressoria was inhibited by concentrations as low as $0.03 \mathrm{mM}$. In vivo tests are planned for the coming season. These results suggest novel applications for biocontrol of apple black spot, with potential for both conventional and organic production systems. 